\title{
Pengaruh Kompensasi Terhadap Motivasi Kerja Serta Dampaknya pada Kinerja Karyawan di Suis Butcher Setiabudhi Bandung
}

\author{
Eva Silviyana Putri ${ }^{1}$, Agus Sudono ${ }^{1}$, Masharyono ${ }^{2}$ \\ ${ }^{1}$ Manajemen Industri Katering, Fakultas Pendidikan Ilmu Pengetahuan Sosial, Universitas \\ Pendidikan Indonesia, Jl. Dr. Setiabudhi No. 229, Bandung 40154, Indonesia \\ ${ }^{2}$ Manajemen Bisnis, Fakultas Pendidikan Ekonomi dan Bisnis, Universitas Pendidikan \\ Indonesia, Jl. Dr. Setiabudhi No. 229, Bandung 40154, Indonesia
}

* Koresponding Penulis. E-mail: evasilviyana@student.upi.edu (Eva Silviyana Putri)

\begin{abstract}
Abstrak
Sumber Daya Manusia merupakan salah satu sumber daya yang paling penting dalam suatu perusahaan atau organisasi untuk mencapai tujuan perusahaan. Kinerja karyawan yang rendah merupakan salah satu masalah yang sering kali terjadi pada suatu perusahaan. Kinerja karyawan yang rendah merupakan masalah yang sering terjadi di Suis Butcher Setiabudhi Bandung yang disebabkan karena banyaknya ketidakdisiplinan karyawan. Fenomena tersebut harus ditangani karena karyawan merupakan salah satu faktor yang menentukan keberhasilan suatu perusahaan. Penelitian ini dilakukan untuk memperoleh (1) gambaran kompensasi, (2) gambaran motivasi kerja karyawan, (3) gambaran kinerja karyawan, (4) pengaruh kompensasi terhadap motivasi kerja karyawan, (5) pengaruh motivasi kerja terhadap kinerja karyawan. Metode yang digunakan dalam penelitian ini adalah cross sectional method dengan teknik sampling nonprobability sampling dengan menggunakan sampling jenuh yang berjumlah 29 responden. Teknik analisas data yang digunakan adalah regresi linier sederhana dengan alat bantu software komputer Statistical Product for Service Solutions (SPSS) 22.0 for windows. Hasil temuan dalam penelitian ini menunjukkan bahwa gambaran kompensasi dalam kategori sesuai, motivasi kerja dalam kategori tinggi, kinerja karyawan dalam kategori tinggi, kompensasi mempengaruhi motivasi kerja karyawan, dan motivasi kerja mempengaruhi kinerja karyawan. Berdasarkan penelitian ini, disarankan dalam segi kompensasi dapat meningkatkan kompensasi tidak langsung yaitu pada pemberian tunjangan untuk karyawan. Dalam segi motivasi kerja disarankan dapat meningkatkan kembali kebutuhan harga diri untuk para karyawan yaitu dengan pemberian reward kepada karyawan berprestasi. Sehingga diharapkan kompensasi dan motivasi kerja perlu diperhatikan lebih lanjut oleh organisasi dalam menunjang peningkatan kinerja karyawan.
\end{abstract}

Kata Kunci: $\quad$ Kompensasi; Motivasi Kerja; Kinerja Karyawan; Suis Butcher Setiabudhi Bandung

\section{Pendahuluan}

Pariwisata merupakan sebuah perjalanan yang dilakukan oleh seseorang dengan maksud berlibur untuk menikmati fasilitas destinasi yang ada. Setiap manusia pasti akan membutuhkan wisata untuk memenuhi kebutuhan baik jasmani maupun rohani. Selain berguna untuk memenuhi kebutuhan psikologis manusia, pariwisata juga memiliki manfaat lain, diantaranya manfaat bagi ekonomi, sosial budaya, lingkungan hidup, nilai pengetahuan, dan masih banyak lagi yang didapat dari adanya pariwisata. Sektor pariwisata dapat dikatakan menjadi salah satu penggerak perekonomian Indonesia. Dampak positif dari sektor pariwisata antara lain menghasilkan devisa negara, menciptakan lapangan kerja, menuntaskan kemiskinan dan pemberdayaan masyarakat, melestarikan lingkungan hidup, meningkatkan ketahanan budaya serta mempererat persahabatan antar bangsa. 
Usaha mengembangkan dunia pariwisata ini didukung dengan UU No.10 Tahun 2009 yang menyebutkan bahwa keberadaan obyek wisata pada suatu daerah akan sangat menguntungkan, antara lain

meningkatnya Pendapatan Asli Daerah (PAD), meningkatnya taraf hidup masyarakat dan memperluas kesempatan kerja.

Jawa Barat merupakan salah satu provinsi yang sedang berkembang, yang juga merupakan salah satu provinsi dengan potensi pariwisata yang beragam. Begitu pula dengan Kota Bandung yang merupakan salah satu Kota Wisata yang berada di Provinsi Jawa Barat. Banyak wisatawan mancanegara dan domestik yang datang ke Bandung untuk melakukan perjalanan wisata. Hal itu karena Bandung memiliki udara yang sejuk, wisata alam yang begitu banyak, wisata buatan, dan juga wisata kuliner. Kota Bandung dijuluki sebagai Paris Van Java yang berarti Kota Paris yang ada di Jawa. Layaknya Kota Paris yang memiliki fashion yang beraneka ragam dan juga sebagai kiblatnya kuliner dunia, begitu juga dengan Bandung yang ternyata juga memiliki aneka macam kuliner. Mulai dari kuliner tradisional, modern, bahkan sampai kuliner tradisional yang diinovasikan menjadi kuliner modern. Namun ternyata, Bandung tidak hanya memiliki aneka kuliner Indonesia yang banyak, namun ada juga kuliner Western, American, Arabic, Korean, Chinnese, Japanese, dll.

Pertumbuhan pariwisata di Kota Bandung mendorong lahirnya berbagai macam usaha di bidang pariwisata seperti adanya hotel, restaurant, cafe, rumah makan, tempat belanja pakaian, dan sebagainya. Sebagai penunjang pariwisata di Kota Bandung, restoran perlu diperhatikan perkembangannya agar tersedianya fasilitas yang menunjang untuk para wisatawan dengan baik.

Suis Butcher Setiabudhi Bandung merupakan salah satu restaurant Steak yang legendaris. Berdiri sejak tahun 1984, yang merupakan salah satu pelopor Menu Steak di
Bandung. Berada di Jl.Setiabudhi No. 174, dan terdapat juga beberapa cabang dijalan lain. Berada di salah satu pusat keramaian kota, membuat Suis Butcher memiliki kesempatan yang baik dalam penjualannya, terutama karena tempat ini sudah sangat legendaris. Restoran ini khusus menyediakan hidangan Steak dengan berbagai macam pilihan daging yang tersedia, lalu juga menyediakan berbagai dessert yang dapat melengkapi sajian menu disini. Suasana yang ditampilkan pun cukup authentic dengan konsep yang masih sama seperti dahulu. Tempat ini tersedia sekitar 27 meja dengan daya tampung 120 orang. Memiliki total 29 orang karyawan.

Adapun masalah yang kerap terjadi di Suis Butcher Setiabudhi ini adalah dalam segi kinerja karyawan. Hal ini sesuai dengan hasil wawancara pada 8 Mei 2017 pukul 10 : 35 WIB, dengan Bapak Erwin selaku supervisor mengatakan bahwa banyak dari karyawan yang sering kali terlambat dalam kehadiran, izin tidak hadir, kerapihan, dan juga kedisiplanan seragam yang kurang baik.

Melihat bagaimana kondisi karyawan Suis Butcher Setiabudhi Bandung yang mengalami penurunan kinerja, Bapak Gilang selaku Restaurant Manager di Suis Butcher mengatakan bahwa rendahnya tingkat kompensasi yang diberikan perusahaan terhadap karyawan, yang membuat karyawan tidak memiliki motivasi dalam bekerja. Dalam wawancara pada Selasa, 8 Mei 2017 pukul 10.35 WIB bahwa pada dasarnya kompensasi yang diberikan oleh Suis Butcher memang masih di bawah UMR Kota Bandung, oleh karena itu banyak sekali karyawan yang merasa kurang termotivasi akibat dari kompensasi yang kurang memuaskan.

Penelitian yang dilakukan oleh Damayanti, Susilaningsih \& Sumaryati (2013) menyatakan bahwa pemberian kompensasi dari perusahaan sebaiknya disesuaikan dengan kinerja yang diciptakan karyawan, motivasi yang dimiliki juga sebaiknya dapat meningkatkan kinerja 
karyawan. Karyawan yang menerima kompensasi dari perusahaan sesuai dengan hasil kinerja karyawan, dan motivasi yang dimiliki seharusnya tetap selalu ada pada diri karyawan saat bekerja sehingga kinerja karyawan akan terus meningkat.

Berdasarkan latar belakang yang telah diuraikan diatas, kompensasi dirasa sangat penting hubungannya dengan motivasi kerja karyawan, dan motivasi kerja karyawan akan berpengaruh terhadap kinerja yang dilakukan oleh karyawan. Peneliti melakukan sebuah penelitian lebih lanjut dengan judul "Pengaruh Kompensasi Terhadap Motivasi Kerja Serta Dampaknya pada Kinerja Karyawan di Suis Butcher Setiabudhi Bandung".

Adapun rumusan masalah dari penelitian ini adalah :

1. Bagaimana gambaran kompensasi di Suis Butcher Setiabudhi Bandung?

2. Bagaimana gambaran motivasi kerja di Suis Butcher Setiabudhi Bandung?

3. Bagaimana gambaran kinerja karyawan di Suis Butcher Setiabudhi Bandung?

4. Adakah pengaruh kompensasi terhadap motivasi kerja karyawan di Suis Butcher Setiabudhi Bandung?

5. Adakah pengaruh motivasi kerja terhadap kinerja karyawan di Suis Butcher Setiabudhi Bandung?

Penelitian ini dilakukan untuk mengetahui pengaruh kompensasi terhadap motivasi kerja karyawan, serta dampaknya kepada kinerja karyawan di Suis Butcher Setiabudhi Bandung, di mana yang menjadi variabel bebas adalah Kompensasi (X), mencakup gaji, upah, insentif, jaminan kesehatan, dan jaminan ketenagakerjaan. Kemudian, yang menjadi variabel intervening yaitu Motivasi Kerja (Y), yang terdiri dari kebutuhan fisiologis, kebutuhan rasa aman, kebutuhan harga diri, kebutuhan sosial, dan kebutuhan aktualisasi diri. Serta yang menjadi variabel terikat yaitu Kinerja Karyawan (Z) yang dimensinya mencakup
Quanlity of Work (kualitas pekerjaan), Quantity of Work (kuantitas pekerjaan), Interpersonal Effectiveness (personal kualitas), Competencies (kompetensi), Job Knowledge (pengetahuan pekerjaan), Dependability (kesadaran diri) dan Creativeness (tingkat kreatifitas) .

\section{Metode Penelitian}

Metode penelitian ini menggunakan cross sectional method yaitu metode penelitian dengan cara mempelajarai objek dalam kurun waktu tertentu (tidak berkesinambungan dalam jangka waktu panjang). Oleh karena itu akan diteliti pengaruh kompensasi terhadap motivasi kerja serta dampaknya pada kinerja karyawan pada Suis Butcher Setiabudhi Bandung periode Januari 2017 - Agustus 2017.

Teknik sampel yang akan digunakan dalam penelitian ini adalah teknik sampling jenuh. Menurut Sugiyono (2014:68) sampling jenuh adalah teknik penentuan sampel bila semua anggota populasi digunakan sebagai sampel. Istilah lain sampel jenuh adalah sensus, dimana semua anggota populasi dijadikan sampel.

Umar (2010, hal. 45), pendekatan cross sectional yaitu metode penelitian dengan cara mempelajari objek dalam kurun waktu tertentu (tidak berkesinambungan dalam jangka waktu panjang) dalam penelitian yang menggunakan metode ini, informasi dari sebagian populasi dikumpulkan langsung di tempat kejadian secara empirik dengan tujuan untuk mengetahui pendapat dari sebagian populasi terhadap objek yang sedang diteliti di lapangan.

Wibowo (2014, hal. 348) kompensasi merupakan kontrasepsi terhadap penggunaan tenaga atau jasa yang telah diberikan oleh tenaga kerja. Wibowo juga mengatakan bahwa kompensasi merupakan jumlah paket yang ditawarkan organisasi kepada pekerja sebagai imbalan atas penggunaan tenaganya untuk bekerja. Pemberian kompensasi merupakan salah 
satu pelaksanaan fungsi MSDM yang berhubungan dengan semua jenis pemberian penghargaan individual sebagai pertukaran dalam melakukan tugas keorganisasian.

Menurut Stephen P.Robbins dan Mary Counter yang dikutip dalam Suwatno (2011, hal. 171) menyatakan motivasi kerja sebagai kesediaan untuk melaksanakan upaya tinggi untuk mencapai tujuan-tujuan keorganisasian yang dikondisikan oleh kemampuan upaya untuk memenuhi kebutuhan individual tertentu.

Mejia, Luis, Balkin \& Cardy (2012, hal. 223) Performance is appraisal includes the identification, measurement, and management of human performance in organization. Penilaian kinerja meliputi identifikasi, pengukuran, dan pengelolaan kinerja manusia dalam organisasi.

\section{Hasil dan Pembahasan}

Rekapitulasi dimensi kompensasi pada 29 orang karyawan Suis Butcher Setiabudhi Bandung dapat dilihat pada Tabel berikut:

Tabel 1. Rekapitulasi Dimensi Kompensasi

\begin{tabular}{lllll}
\hline No & Dimensi & $\begin{array}{l}\text { Total } \\
\text { Skor }\end{array}$ & $\begin{array}{l}\text { Skor } \\
\text { Ideal }\end{array}$ & $\%$ \\
\hline 1 & $\begin{array}{l}\text { Kompensasi } \\
\text { Langsung }\end{array}$ & 1217 & 1421 & $86 \%$ \\
2 & $\begin{array}{l}\text { Kompensasi } \\
\text { Tidak }\end{array}$ & 325 & 406 & $80 \%$ \\
& $\begin{array}{l}\text { Langsung } \\
\text { Total }\end{array}$ & 1542 & 1827 & $84 \%$ \\
\hline Sumber : & Data diolah, 2017 & &
\end{tabular}

Berdasarkan aspek Kompensasi paling tinggi pyaitu terdapat pada dimensi kompensasi langsung memperoleh skor sebanyak 1217 atau 86\%, sementara dimensi tidak langsung hanya mendapat skor 325 atau $80 \%$. Secara keseluruhan variabel Kompensasi memperoleh skor 1542. Apabila di persentasekan ke dalam skor ideal maka diperoleh persentase sebesar $84 \%$, dapat dikatakan bahwa hampir seluruh karyawan menyatakan bahwa Kompensasi di Suis Butcher Setiabudhi Bandung dalam kategori sesuai. Sebagaimana dinyatakan bahwa kompensasi menjadi salah satu faktor yang dominan dalam memotivasi seseorang untuk meningkatkan kinerjanya (Masruroh, Thomas, \& Latifah, 2012, hal. 2).

Rekapitulasi dimensi motivasi kerja pada 29 orang karyawan Suis Butcher Setiabudhi Bandung dapat dilihat pada tabel berikut ini :

Tabel 2. Rekapitulasi Dimensi Motivasi Kerja Karyawan Suis Butcher Setiabudhi Bandung

\begin{tabular}{llcll}
\hline No & Dimensi & $\begin{array}{l}\text { Total } \\
\text { Skor }\end{array}$ & $\begin{array}{l}\text { Skor } \\
\text { Ideal }\end{array}$ & $\%$ \\
\hline 1 & $\begin{array}{l}\text { Kebutuhan } \\
\text { Fisiologis }\end{array}$ & 321 & 406 & $79 \%$ \\
2 & $\begin{array}{l}\text { Kebutuhan } \\
\text { Rasa Aman }\end{array}$ & 330 & 406 & $81 \%$ \\
3 & $\begin{array}{l}\text { Kebutuhan } \\
\text { Sosial }\end{array}$ & 346 & 406 & $85 \%$ \\
4 & $\begin{array}{l}\text { Kebutuhan } \\
\text { Harga Diri }\end{array}$ & 317 & 406 & $78 \%$ \\
& $\begin{array}{l}\text { Kebutuhan } \\
\text { Aktualisasi }\end{array}$ & 331 & 406 & $82 \%$ \\
& $\begin{array}{l}\text { Total } \\
\text { Sumber : Data diolah, 2017 }\end{array}$ & 2030 & $81 \%$ \\
\hline
\end{tabular}

Berdasarkan aspek Motivasi Kerja paling tinggi yaitu terdapat pada dimensi kebutuhan sosial memperoleh skor sebanyak 346 atau $85 \%$, sementara dimensi kebutuhan harga diri hanya mendapat skor 317 atau $78 \%$. Secara keseluruhan variabel Motivasi Kerja memperoleh skor 1645. Apabila di persentasekan ke dalam skor ideal maka diperoleh persentase sebesar $81 \%$, dapat dikatakan bahwa hampir seluruh karyawan menyatakan bahwa Motivasi Kerja di Suis Butcher Setiabudhi Bandung dalam kategori tinggi.

Tabel 3. Rekapitulasi Dimensi Kinerja Karyawan

\begin{tabular}{|c|c|c|c|c|}
\hline No & Dimensi & $\begin{array}{l}\text { Total } \\
\text { Skor }\end{array}$ & $\begin{array}{l}\text { Skor } \\
\text { Ideal }\end{array}$ & $\%$ \\
\hline 1 & $\begin{array}{l}\text { Quality of } \\
\text { Work }\end{array}$ & 339 & 406 & $83 \%$ \\
\hline 2 & $\begin{array}{l}\text { Quantity of } \\
\text { Work }\end{array}$ & 337 & 406 & $83 \%$ \\
\hline 3 & $\begin{array}{l}\text { Interpersona } \\
\text { Effecktiveness }\end{array}$ & 531 & 609 & $87 \%$ \\
\hline 4 & Competencies & 533 & 609 & $88 \%$ \\
\hline 5 & $\begin{array}{l}\text { Job } \\
\text { Knowledge }\end{array}$ & 515 & 609 & $85 \%$ \\
\hline 6 & Dependability & 366 & 406 & $90 \%$ \\
\hline 7 & Creativeness & 334 & 406 & $82 \%$ \\
\hline
\end{tabular}




\begin{tabular}{ccccc}
\hline \multirow{2}{*}{ No } & \multirow{2}{*}{ Dimensi } & $\begin{array}{c}\text { Total } \\
\text { Skor }\end{array}$ & $\begin{array}{c}\text { Skor } \\
\text { Ideal }\end{array}$ & $\%$ \\
\hline & Total & 2955 & 3451 & $86 \%$ \\
\hline
\end{tabular}

Sumber : Data diolah, 2017

Berdasarkan aspek Kinerja Karyawan paling tinggi yaitu terdapat pada dimensi dependability memperoleh skor sebanyak 366 atau 90\%, sementara skor terendah terdapat pada dimensi creativeness hanya mendapat skor 334 atau 82\%. Secara keseluruhan variabel Kinerja karyawan memperoleh skor 2955. Apabila di persentasekan ke dalam skor ideal maka diperoleh persentase sebesar $86 \%$, dapat dikatakan bahwa hampir seluruh karyawan menyatakan bahwa Kinerja Karyawan di Suis Butcher Setiabudhi Bandung dalam kategori efektif.

\subsection{Pengujian Verifikatif Variabel $\mathrm{X}$ Terhadap Variabel Y}

Variabel bebas dalam penelitian ini yaitu Kompensasi (X) sedangkan untuk variabel terikatnya adalah Motivasi Kerja (Y). Untuk menguji ada tidaknya pengaruh bebas terhadap variabel terikat, dilakukan dengan pengujian regresi sederhana.

$$
\mathrm{Y}=\mathrm{a}+\mathrm{bX}
$$

$Y=16,493+0,772 X$

Berdasarkan persamaan regresi linear sederhana diatas, nilai constanta sebesar 16,493 menyatakan bahwa jika tidak ada kompensasi, maka besarnya motivasi kerja karyawan 16,493. Koefisien regresi pada variabel kompensasi adalah 0,772 yang artinya setiap terjadi penambahan nilai kompensasi maka akan terjadi peningkatan motivasi kerja karyawan sebesar 0,772. Sebaliknya, jika terjadi penurunan motivasi kerja, kompensasi akan menurunkan motivasi kerja karyawan sebesar 0,772 satu satuan nilai. Dapat dikatakan bahwa kompensasi yang diberikan perusahaan kepada karyawan berpengaruh terhadap tingkat motivasi kerja karyawan. Jika kompensasi kurang efektif, maka motivasi kerja karyawan akan rendah.

Analisis koefisien determinasi digunakan untuk mengetahui persentase pengaruh yang terjadi dari variabel bebas terhadap variabel terikat. Sehingga dalam penelitian ini koefisien determinasi digunakan untuk mengetahui besarnya persentase pengaruh $\mathrm{X}$ terhadap Y. Sehingga rumus yang digunakan adalah menurut Riduwan (2013, hal. 136), yaitu:

$$
\mathrm{KD}=\mathrm{r}^{2} \times 100 \%
$$

Berikut adalah hasil perhitungan koefisien determinasi dari $\mathrm{X}$ terhadap $\mathrm{Y}$ : $\mathrm{KD}=\mathrm{r} 2 \times 100 \%$

$$
\begin{aligned}
& =(0,772) 2 \times 100 \% \\
& =0,596 \times 100 \% \\
& =59,6 \%
\end{aligned}
$$

Hasil perhitungan koefisien determinasi di atas untuk kompensasi

(X) terhadap motivasi kerja (Y) menghasilkan persentase sebesar 59,6\%. Dengan kata lain, motivasi kerja dipengaruhi $59,6 \%$ oleh kompensasi, sedangkan $40,4 \%$ dipengaruhi oleh faktorfaktor lainnya diluar kompensasi yaitu lingkungan kerja, dan pengembangan karyawan.

\subsection{Pengujian Verifikatif Variabel $Y$ Terhadap Variabel Z}

Variabel bebas dalam penelitian ini yaitu motivasi kerja (Y) sedangkan untuk variabel terikatnya adalah kinerja karyawan (Z). Untuk menguji ada tidaknya pengaruh bebas terhadap variabel terikat, dilakukan dengan pengujian regresi sederhana.

$\mathrm{Y}=8,354+0,815 \mathrm{X}$

$$
\mathrm{Y}=\mathrm{a}+\mathrm{bX}
$$

Berdasarkan persamaan regresi linear sederhana diatas, nilai konstanta sebesar 8,354 menyatakan bahwa jika tidak ada motivasi kerja, maka besarnya kinerja karyawan 8,354. Koefisien regresi pada variabel kinerja karyawan adalah 0,815 yang artinya setiap terjadi penambahan nilai 
motivasi maka akan terjadi peningkatan kinerja karyawan sebesar 0,815 . Sebaliknya, jika terjadi penurunan kinerja karyawan, motivasi kerja akan menurun sebesar 0,815 satu satuan nilai. Dapat dikatakan bahwa motivasi kerja karyawan berpengaruh terhadap tingkat kinerja karyawan. Jika motivasi kerja kurang efektif, maka kinerja karyawan akan rendah.

Analisis koefisien determinasi digunakan untuk mengetahui persentase pengaruh yang terjadi dari variabel bebas terhadap variabel terikat. Sehingga dalam penelitian ini koefisien determinasi digunakan untuk mengetahui besarnya persentase pengaruh $\mathrm{Y}$ terhadap $\mathrm{Z}$.

Berikut adalah hasil perhitungan koefisien determinasi dari Y terhadap $\mathrm{Z}$ :

$$
\begin{aligned}
\mathrm{KD}= & \mathrm{r} 2 \times 100 \% \\
& =(0,815) 2 \times 100 \% \\
& =0,6642 \times 100 \% \\
& =66,42 \%
\end{aligned}
$$

Hasil perhitungan koefisien determinasi di atas untuk motivasi kerja (Y) terhadap kinerja karyawan (Z) menghasilkan persentase sebesar $66,42 \%$. Dengan kata lain, kinerja karyawan dipengaruhi $66,42 \%$ oleh motivasi, sedangkan $33,58 \%$ dipengaruhi oleh faktorfaktor lainnya diluar motivasi yang tidak diteliti dalam penelitian ini, yaitu kepuasan kerja, kepemimpinan, tingkat stress, dan lingkungan kerja. Seperti hasil penelitian Nuryanti \& Rahmawati (2016) bahwa faktor yang mempengaruhi kinerja karyawan adalah motivasi, kepuasan kerja, kepemimpinan, tingkat stress, lingkungan kerja, aspek ekonomi, kompensasi, dan kondisi lingkungan fisik lokasi kerja.

\section{Kesimpulan}

Kompensasi dapat ditingkatkan lagi pada aspek kompensasi finansial tidak langsung atau tunjangan dengan memperbaiki dan meningkatkan kompensasi yang telah dijalankan, khususnya adanya penambahan dalam tunjangan asuransi kecelakaan kepada karyawan sehingga dapat menjadi pemacu dalam meningkatkan motivasi kerja karyawan.

Motivasi dapat ditingkatkan lagi pada aspek kebutuhan harga diri khususnya pada indikator perusahaan memberikan apresiasi terhadap karyawan yang berprestasi. Hal tersebut dapat dilakukan dengan adanya penghargaan bagi karyawan yang berprestasi, sehingga diharapkan karyawan dapat termotivasi untuk meningkatkan kualitas kinerjanya.

Kinerja karyawan dapat ditingkatkan lagi pada aspek kreatifitas, khususnya pada indikator mampu memunculkan ide atau gagasan yang kreatif selama bekerja. Hal tersebut dapat dilakukan cara yang berbedabeda tergantung dari jenis divisi masingmasing misalkan pada divisi service yang menggunakan aksesoris bernuansa pink pada saat perayaan hari valentine, divisi kitchen menciptakan menu baru sesuai dengan yang sedang diminati saat ini tanpa harus meninggalkan ciri khas dari menu Suis Butcher, divisi cleaning service yang mengusulkan adanya penambahan tempat sampah organik dan anorganik di area restoran yang disediakan untuk tamu dan juga diarea kitchen, dengan pemilihan sampah tersebut diharapkan sampah anorganik dapat dijual kembali sehingga dapat menjadi nilai ekonomis bagi perusahaan.

Hasil penelitian menyatakan bahwa kompensasi berpengaruh terhadap motivasi kerja karyawan, dengan demikian penulis menyatakan agar pihak perusahaan dapat memberikan kompensasi yang lebih baik kepada karyawan, sehingga karyawan pun akan semakin loyal kepada perusahaan dan juga akan meningkatkan motivasi nya dalam bekerja.

Hasil penelitian menyatakan bahwa motivasi kerja berpengaruh terhadap kinerja karyawan, dengan demikian penulis menyatakan agar pihak perusahaan dapat memberikan motivasi yang lebih baik kepada karyawan misalnya dengan diadakannya kompetensi bagi karyawan yang dapat mengajak atau mempromosikan 
teman atau keluarganya makan di Suis Butcher, maka akan mendapatkan skor tambahan untuk penilaian evaluasi kinerjanya. Diharapkan dengan adanya kompetensi tersebut dapat meningkatkan penjualan di Suis Butcher sehingga karyawan juga mendapat kompensasi yang lebih, serta termotivasi untuk terus melakukan pekerjaan yang kreatif.

\section{Daftar Pustaka}

Damayanti, A., Susilaningsih, \& Sumaryati, S. (2013). Pengaruh Kompensasi dan Motivasi Kerja terhadap Kinerja Karyawan Perusahaan Air Minum (PDAM). JUPE UNS , 155-168.

Masruroh, U., Thomas, P., \& Latifah, L. (2012). Pengaruh Kompensasi dan Disiplin Kerja Terhadap Kinerja Guru Ekonomi SMA Negeru Brebes. Universitas Negeri Malang, 1-7.

Mejia, G., Luis, R., Balkin, D. B., \& Cardy, R. L. (2012). Managing Human Resources. New Jersey: Pearson Education.

Nuryanti, L., \& Rahmawati, R. (2016). The Influence of Situasional Leadership and Work Environment towards Employees' Performance. Advances in Economic, Business, and Management Research, 540-543.

Riduwan. (2013). Belajar Mudah Penelitian. Bandung: Alfabeta.

Suwatno, d. J. (2011). Manajemen SDM Dalam Organisasi Publik dan Bisnis .Bandung: Alfabeta

Umar, H. (2010). Metode riset Bisnis. Bandung: Alfabeta.

Wibowo. (2014). Manajemen Kinerja. Jakarta: PT. Rajagrafindo Persada. 